\title{
Chemical properties of the test of ascidians in relation to predation
}

\author{
David L. Parry \\ Chemistry Department, University of Queensland, Brisbane, Australia, 4067
}

\begin{abstract}
The undamaged test of a range of aplousobranch ascidian species is shown to be chemically neutral. Acid is generated by surface test cells following cell lysis and is rapidly neutralised in the presence of calcareous test inclusions and/or sea water. Neither the capacity to produce acid nor the presence of vanadium prevents predation on ascidian species in the field.
\end{abstract}

\section{INTRODUCTION}

Stoecker $(1980 a, b, c)$ has proposed that low intracellular $\mathrm{pH}$ in the tunic fluids and high vanadium content of some aplousobranch and phlebobranch ascidians might prevent or inhibit predation. Intercellular acidity of ascidian tests has been observed in connection with investigations on Prochloron symbionts in the family Didemnidae which are either embedded in the test, or contained in the common cloacal cavity or loosely associated on the surface (Thinh and Griffiths, 1977; Thorne et al., 1977). All symbionts, but especially those embedded in the test, would be subjected to a low $\mathrm{pH}$ if reports of intercellular acidity in the ascidian test are accurate. Attempts to culture Prochloron at low $\mathrm{pH}$ (Patterson and Withers, 1982) did not survive more than 3 generations (G. M. L. Patterson, pers. comm.). More compelling evidence that challenges the view that low intercellular $\mathrm{pH}$ is a normal property of the test of living aplousobranch ascidians is the fact that many of the living species in which it has been reported contain calcareous spicules in the test.

Further, the hypothesis that vanadium inhibits predation is not applicable to all members of the class. High concentrations of vanadium are present in Phlebobranch species but it is not commonly found in appreciable amounts in Aplousabranchia and is not found at all in the Stolidobranchia (Hawkins et al., 1983a).

The following report sets out investigations on the $\mathrm{pH}$ of ascidian tests and assessments of vanadium content and these are correlated with field observations on ascidian predation.

\section{METHODS AND RESULTS}

All species were collected from cryptic habitats just below low water mark at Heron Island, Great Barrier Reef.

Species tested: Family Polycitoridae: Eudistoma amplus, Eudistoma sp., Cystodytes dellechiajei; Family Polyclinidae: Aplidium sp., Polyclinum macrophyllum; Family Didemnidae: Didemnum molle, $D$ sphaericum, D. digestum, D. psammatodes, D. membranaceum, D. aff. chartaceum, D. proliferum, D. viride, Trididemnum sp., T. clinides, T. miniatum, T. cyclops, T. paracyclops, T. cerebriforme, Lissoclinum voeltzkowi, L. bistratum, L. patella, L. punctatum, $L$. ostrearium, L. fragile, Echinoclinum triangulum, Diplosoma virens, D. similis, D. listerianum, Leptoclinides sp., L. lissus, $L$. reticulatus.

A range of $\mathrm{pH}$ indicator stains (neutral red, methyl red, bromocresol green and bromophenol blue) added to living colonies in sea water show that no part of the whole undamaged colonies are acid and $\mathrm{pH}$ was 6.5 to 7.0 in all cases. However, lysis of the external bladder cells with a probe produces acid at $\mathrm{pH} \leq 3.5$ in the majority of species tested (Table 1). These measurements were made on at least 6 individuals of each species. In species in which the spicules are so crowded that the bladder cell layer is occluded, there was no acid reaction: Lissoclinum bistratum, Didemnum sphaericum, $D$. proliferum, D. psammatodes, $D$. membranaceum. The reaction seems not to be homologous with the reaction that generates a low $\mathrm{pH}$ on lysis of the blood cells of phlebobranch species (Hawkins et al., 1983b). The presence of calcareous 
Table 1. Predators, vanadium content and $\mathrm{pH}$ of ascidians

\begin{tabular}{|c|c|c|c|c|c|}
\hline Ascidian species & Predator & $\mathrm{pH}^{\mathrm{i}, \mathrm{a}}$ & $\begin{array}{l}\text { Vanadium }{ }^{1 . a} \\
\text { (ppm dry weight) }\end{array}$ & $\begin{array}{l}\text { Latitudinal } \\
\text { Zone }\end{array}$ & $\begin{array}{l}\text { Refe- } \\
\text { rence }\end{array}$ \\
\hline \multirow[t]{2}{*}{ Leptoclinides sp. } & Chromodoris sp. & & & & \\
\hline & Lamellaria sp. & 2.0 & 10000 & TR & 1 \\
\hline Leptoclinides reticulatus & Turbo crassus & $<3.5$ & 10000 & $\mathrm{TR}$ & 1 \\
\hline Eudistoma sp. & Trochus niloticus & $<3.5$ & 1200 & TR & 1 \\
\hline E. amplus & $T$ niloticus & $<3.5$ & 880 & $\mathrm{TR}$ & 1 \\
\hline Polyclinum macrophyllum & $T$ niloticus & 7.0 & $<20$ & TR & 1 \\
\hline Lissoclinum ostrearium & $T$ niloticus & $<3.5$ & $<20$ & TR & 1 \\
\hline \multirow[t]{2}{*}{ Didemnum membranaceum } & Cypraea sp. & & & & \\
\hline & Lamellaria sp. & 7.0 & $<20$ & TR & 1 \\
\hline Cystodytes dellechiajei & Cypraea sp. & 2.0 & $<20$ & TR & 1 \\
\hline \multirow[t]{2}{*}{ Atriolum sp. } & Cymatid mollusc & $<3.5$ & $<20$ & TE & 2 \\
\hline & Starfish & & & & \\
\hline \multirow[t]{2}{*}{ Amarouciun spp. } & $\begin{array}{l}\text { Mediaster aequalis } \\
\text { Pteraster tesselatus }\end{array}$ & & & & \\
\hline & Dermasterias imbricata & $(<3.5)$ & - & $\mathrm{TE}$ & 3 \\
\hline \multirow[t]{2}{*}{ Didemnum spp. } & Pteraster tesselatus & & & & \\
\hline & Dermasterias imbricata & $(<3.5)$ & $(<20)$ & $T E$ & 3 \\
\hline Eudistoma psammion & Dermasterias imbricata & $\leqq 2.0^{12}$ & $>100^{12}$ & TE & 3 \\
\hline \multirow[t]{2}{*}{ Corella spp. } & Solaster endeca & & & & \\
\hline & Mediaster aequalis & - & $<20^{10}$ & TE & 3 \\
\hline Pyura haustor & Solaster stimpsoni & $170)$ & $(2010$ & & $x$ \\
\hline \multirow[t]{2}{*}{ Chelyosoma productum } & Evasterias troschelii & $(<3.5)$ & $800^{11}$ & TE & 3 \\
\hline & Molluscs & & & & \\
\hline Didemnum moseleyi & Hexabranchus sanguineus & $<3.5^{1}$ & $<20^{1}$ & TR & 4 \\
\hline Diplosoma sp. & Trivia sp. & $(<3.0)$ & $(<20)$ & TE & 5,6 \\
\hline \multirow[t]{2}{*}{ Trididemnum sp. } & Trivia monacha & & & & \\
\hline & T. arctica & $(<3.5)$ & $(<20)$ & TE & 6 \\
\hline \multirow[t]{2}{*}{ Polyclinum sp. } & T monacha & & & & \\
\hline & T. arctica & 7.0 & $<20$ & TE & 6 \\
\hline Didemnum sp. & Lamellaria perspicua & $(<3.5)$ & $(<20)$ & TE & 6 \\
\hline Phallusia sp. & Velutina velutina & $<3.0^{1}$ & $>1000^{10}$ & TE & 6 \\
\hline Ascidia mentula & Pleurobranchus membranaceus & $(<3.0)$ & $>1000^{13}$ & TE & 7 \\
\hline \multirow[t]{2}{*}{ Diplosoma listerianum } & $\begin{array}{l}\text { Goniodoris nodosus } \\
\text { G. castanea }\end{array}$ & & & & \\
\hline & Ancula cristata & $<3.0^{1}$ & $<20^{\mathrm{t}}$ & TE & 8 \\
\hline \multirow[t]{3}{*}{ Botryllus schlosseri } & $\begin{array}{l}\text { Goniodoris nodosus } \\
\text { G. castanea } \\
\text { Ancula cristata }\end{array}$ & & & & \\
\hline & Erato voluta & $7.0^{1}$ & $<20^{1}$ & - & 5,8 \\
\hline & Fish & & & & \\
\hline Distaplia viridis & Penicipelta vittiger & $(<3.5)$ & $>1000$ & TE & 9 \\
\hline Botrylloides sp. & $P$. vittiger & $(7,0)$ & $(<20)$ & TE & 9 \\
\hline \multicolumn{6}{|c|}{$\begin{array}{l}\text { Damaged colonies, values in parentheses extrapolated from this work } \\
\text { b TR, tropical; TE, temperate } \\
1 \text { This work }\end{array}$} \\
\hline \multicolumn{3}{|l|}{2 Kott, pers. comm. } & \multicolumn{3}{|c|}{10 Hawkins et al (1983a) } \\
\hline${ }^{3}$ Mauzey et al. (1968) & \multicolumn{2}{|c|}{7 Thompson and Slinn (1959) } & \multicolumn{2}{|c|}{ 1) Danskin (1978) } & \\
\hline \multirow{2}{*}{\multicolumn{3}{|c|}{$\begin{array}{l}4 \text { Thompson }(1970) \\
5 \text { Purchon }(1977)\end{array}$}} & \multicolumn{3}{|c|}{12 Swinehart et al. (1974) } \\
\hline & & & \multicolumn{2}{|c|}{13 Ciereszko et al. (1963) } & \\
\hline
\end{tabular}

spicules causes extremely rapid neutralisation of the acid generated. However, even without spicules, as in Diplosoma spp., sea water is sufficient buffer to neutralise the acid generated on cell lysis. Six colonies of
Diplosoma virens crushed in only $15 \mathrm{ml}$ of sea water produced a $\mathrm{pH} 7.0$.

The concentrations of vanadium were $<20$ ppm dry weight in all species tested, except Leptoclinides spp. 
in which the concentration is 10,000 ppm dry weight and Eudistoma spp. with $880 \mathrm{ppm}$ dry weight. At least 4 individuals of each species were analysed for vanadium. The vanadium was determined by flame atomic absorption using either a Varian AA6 or Varian 875 spectrometer. In the determination of vanadium there is a large matrix effect which is corrected by the method of standard additions.

Results of field observations are presented in Table 1, together with other reports of predation from the literature

\section{DISCUSSION}

Diverse communities of encrusting ascidians on the under surface of rubble behind the reef crest at Heron Island (Great Barrier Reef) are grazed by a number of species of molluscs, in particular, Trochus niloticus (Fig. 1). Some boulders may have up to 20 species of ascidians, many with acid producing cells, some with high vanadium and some with both; yet some of these boulders are completely denuded by $T$. niloticus, Cypraea sp. and many other species of molluscs.

There are many predators on ascidians ranging from molluscs to fishes (Table 1). Many molluscs feed on a wide range of ascidians: from stolidobranch ascidians, which have no vanadium and produce no acid, to Phlebobranchs and Aplousobranchs which have high vanadium content and produce acid. Molluscs are more frequently recorded predators - due to being less active and spending more time in attacking their prey - and therefore are more readily observed. Only few ascidians have parts, calcareous spicules and in some the test, which sufficiently withstand digestion to facilitate identification. It is therefore not surprising that there are few records of ascidians forming part of the diet of fish and this may be in part the reason they are commonly regarded as distasteful (Millar, 1971). There are reports of fish predation; but they do not in all cases indicate the species of ascidians eaten (Randall and Hartman, 1968; Millar, 1971).

Nevertheless, Trochus niloticus was observed to feed on a wide range of ascidian species in the field; aquarium feeding experiments with $T$. niloticus over a period of $3 \mathrm{wk}$ were unsuccessful (see also Mauzey, 1968).

The absence of epibionts on the surface of colonial aplousobranch ascidians may be a result of the ability of these surface cells to generate acid when damaged, as would occur when an epiphyte attempted to attach itself to the surface. However, the colonial stolidobranchs - Botrylloides nigrum, B. magniceocus, Botryllus schlosseri and $B$. primigenus - have no acid producing cells and no vanadium, yet they are also free of epibionts.

\section{CONCLUSION}

The internal environment of ascidians is never acid and Prochloron and other commensal organisms in the

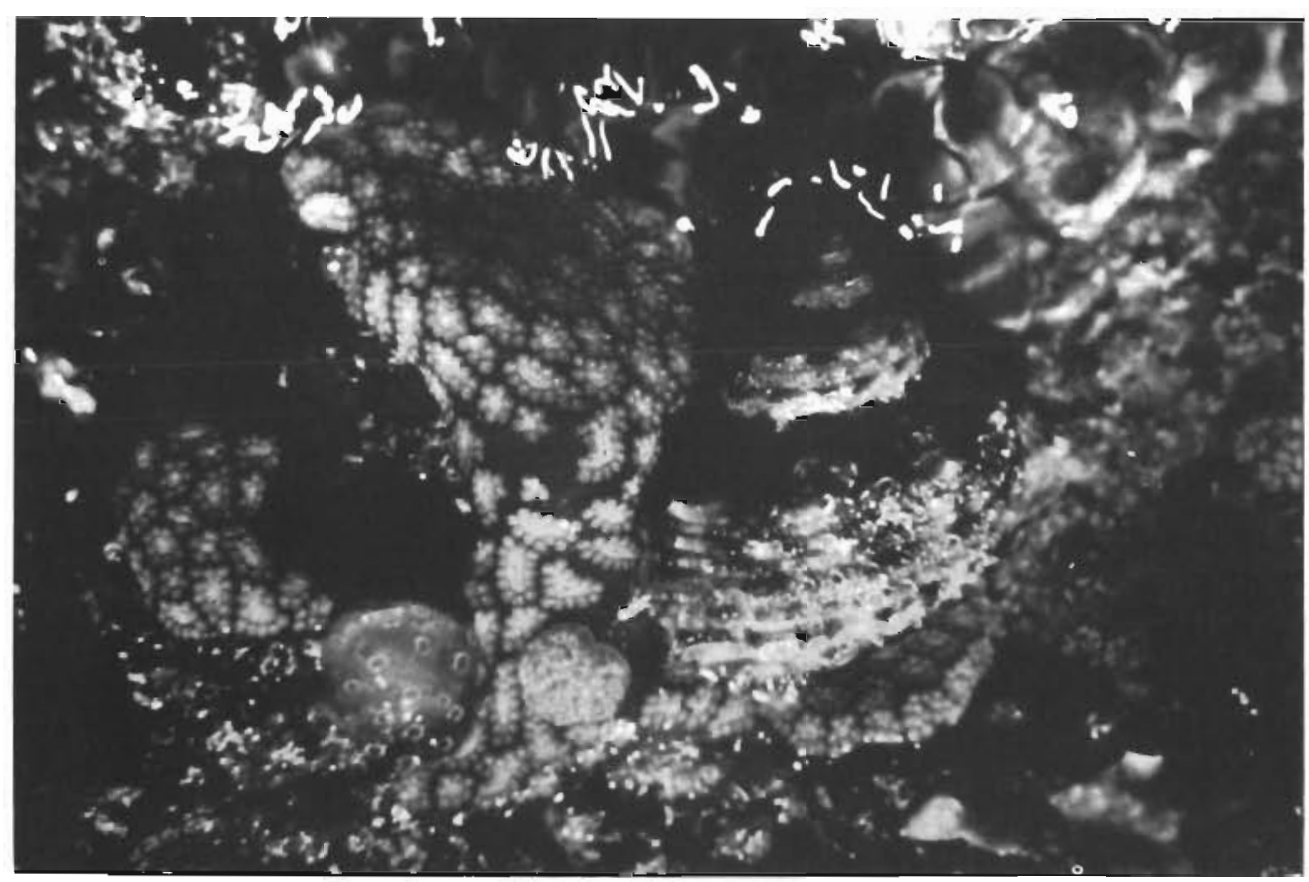

Fig. 1 Trochus niloticus feeding on Eudistoma sp., Heron Island (Great Barrier Reef). Photograph: Professor J. H. Swinehart 
test and in the common cloaca of these colonial organisms occupy a neutral environment. The rapid neutralisation of acid generated on cell lysis appears to preclude its suggested role as a defence against predation. Further, it appears to be very doubtful that the capacity to concentrate vanadium to a high level is a mechanism of chemical defense.

Acknowledgements. I thank Dr. P. Kott for her assistance in identifying the ascidians and her advice on many aspects of this work. Specimens are deposited in the Queensland Museum. The project was partly supported by a grant from the Great Barrier Reef Marine Park Authority. The investigation was pursued at the Heron Island Research Station.

\section{LITERATURE CITED}

Ciereszko, L. S., Ciereszko, E. M., Harris, E. R., Lane, C. A. (1963). Vanadium content of some tunicates. Comp. Biochem. Physiol. 8: 137-140

Danskin, G. P. (1978). Accumulation of heavy metals by some solitary tunicates. Can. J. Zool. 56: 547-551

Fretter, V., Graham, A. (1962). British prosobranch molluscs. Their functional anatomy and ecology. Ray Society, London

Hawkins, C. J., Kott, P., Parry, D. L., Swinehart, J. H. (1983a). Vanadium content and oxidation state related to ascidian phylogeny. Comp. Biochem. Physiol. 76 B: 555-558

Hawkins, C. J., James, G. A., Parry, D. L., Swinehart, J. H., Wood, A. L. (1983b). Intracellular ascidity in the ascidian. Comp. Biochem. Physiol. 76 B: 559-565

Mauzey, K. P., Birkeland, C., Dayton, P. K. (1968). Feeding behaviour of Asteroids and escape responses of their prey in the Puget Sound region. Ecology 49: 603-619
Millar, R. H. (1971). The biology of ascidians. Adv, mar. Biol 9: $1-100$

Patterson, G. M. L., Withers, N. W. (1982). Laboratory cultivation of Prochloron, a tryptophan auxotroph. Science, N.Y 217: 1034-5

Purchon, R. D. (1977). The biology of the mollusca. Pergamon Press, New York

Randall, J. E., Hartman, W. D. (1968). Sponge-feeding fishes of the West Indies. Mar. Biol. 1: 216-225

Russ, G. R. (1980). Effects of predation by fishes, competition, and structural complexity of the substratum on the establishment of a marine epifaunal community. J. exp. mar. biol. Ecol. 42: 55-69

Stoecker, D. (1980a). Distribution of acid and vanadium in Rhopalaea birkelandi Tokioka. J. exp. mar. biol. Ecol. 48 $277-281$

Stoecker, D. (1980b). Relationships between chemical defense and ecology in benthic ascidians. Mar. Ecol. Prog. Ser. 3: 257-265

Stoecker, D. (1980c). Chemical defenses of ascidians against predators. Ecology 61: 1327-1334

Swinehart, J. H., Biggs, W. R., Halko, D. J., Schroeder, N. C. (1974). The vanadium and selected meta! contents of some ascidians. Biol. Bull. mar. biol. Lab., Woods Hole 146: 302-312

Thinh, L.-V., Griffiths, D. J. (1977). Studies of the relationship between the ascidian Diplosoma virens and its associated microscopic algae. Aust. J. mar. Freshwat. Res. 28: 673-681

Thompson, T. E. (1970). Observations on Hexabranchus from the Australian Great Barrier Reef. Veliger 15: 1-5

Thompson, T. E., Slinn, D. J. (1959). On the biology of the opistobranch Pleurobranchus membranaceus. J, mar. biol. Ass. U.K. 38: 507-524

Thorne, S. W., Newcomb, E. H., Osmond, C. B. (1977). Identification of chlorophyll $b$ in extracts of prokaryotic algae by fluorescence spectroscopy. Proc. natn. Acad. Sci. USA 74: 575-578 